Indo. J. Chem. Res, 2020, 7(2), 127-140

\title{
PEMODELAN HOMOLOGI KOMPARATIF FABP BELALANG KEMBARA (Locusta migratoria) DENGAN PHYRE2 DAN SKRINING VIRTUAL INHIBITOR POTENSIAL
}

\section{Comparative Homology Modeling of Fatty-Acid Binding Protein (FABP) from Locusta migratoria Using Phyre2 and Virtual Screening for Potent Inhibitors}

\author{
Fredy Z. Saudale*, Irenes R.S. Suatu \\ Program Studi Kimia, Fakultas Sains dan Teknik, Universitas Nusa Cendana, \\ Jl. Adisucipto, Penfui, Kupang, NTT
}

*Corresponding author, e-mail: fredy_saudale@staf.undana.ac.id

Received: Nov. 2019 Published: Jan. 2020

\begin{abstract}
The outbreak of locusta migratoria has caused a local crisis in production and cultivation of agricultural crops in East Nusa Tenggara Province. FABP (Fatty Acid-Binding Protein) plays an important role in transporting fatty acids from cytoplasm into mitochondria to generate ATP energy for locusta to fly and migrate. FABP inhibition is an attractive strategy to be exploited for novel insecticide development. Comparative homology modeling using Phyre 2 had been used to generate two FABP models built from desert locusta (Schistocerca gregaria, 98\% percent identity) and mice (Mus musculus, $40 \%$ percent identity) FABP protein as templates. Both FABP models showed an acceptable quality of stereochemistry and structural energy with lower atomic clash scores after refinement. Virtual screening identified potent inhibitor candidates with highest affinity energies which are (i) a heterocyclic compound C00628966 (-10.2 kcal/mol) and (iii) an imidazole derivative C15721579 (-8.5 kcal/mol) that were stabilized through a hydrogen bond with Ser53 also (iii) a pyrimidine derivative C73698912 $(-8.1 \mathrm{kcal} / \mathrm{mol})$ stabilized through hydrogen bonds with Thr57, Thr62 and Ser55. Their interactions resemble inhibitors that have been known to inhibit homologous FABP in humans. Therefore, these compounds warrant further in vitro validation and assay for development of selective insecticides to control locusta population.
\end{abstract}

Keywords: Locusta migratoria, FABP, modelling, PHYRE2.

\section{PENDAHULUAN}

Dalam rangka pemanfaatan lahan kering kepulauan untuk mendukung produksi dan ketahanan pangan di Nusa Tenggara Timur (NTT), tantangan dan hambatan berupa ledakan hama belalang kembara (locusta migratoria) masih terus dijumpai dan belum dapat dituntaskan hingga saat ini (Lassa, 2017). Belalang kembara secara berkala menimbulkan kerugian diberbagai komoditas budidaya pertanian seperti padi dan jagung (Lassa, 2017). Insektisida yang umum dan paling banyak digunakan dipasaran terhadap serangan hama belalang kembara saat ini mengandung senyawa-senyawa kimia aktif yang termasuk dalam golongan karbamat, organofosfat dan piretroid (Nawaz dkk., 2016). Namun demikian kekurangan dari insektisida golongan karbamat, organofosfat, piretroid dan organoklorin yang bersifat neuroaktif adalah efek toksisitasnya terhadap kesehatan manusia dan lingkungan (Cortés-Eslava dkk., 2018). Selain itu, resistansi serangga terhadap golongan insektisida tersebut juga telah dilaporkan terus meningkat (Yang dkk., 2009). Oleh karenanya adalah suatu urgensi untuk mengembangkan insektisida dengan target molekul yang baru.

Fatty Acid Binding Protein (FABP) berpotensi untuk dikembangkan sebagai target protein baru dalam desain dan pengembangan insektisida yang selektif. FABP berperanan penting dalam mengangkut asam lemak untuk disimpan sebagai trigliserida (TG) di lipid droplet sitoplasma maupun untuk diproses sebagai substrat beta oksidasi menghasilkan energi ATP di mitokondria (Hotamisligil dan Bernlohr, 2015). Substrat dari FABP belalang kembara adalah asam lemak oleat yang berinteraksi pada kantong pengikatan melalui ikatan hidrogen dengan residu Arg109, Arg129 dan Tyr131 dan beberapa residu 
non polar melalui ikatan hidrofobik (Lücke dkk., 2006). Inhibisi aktivitas FABP oleh senyawa kimia disitus tempat pengikatan substrat asam oleat dapat diprediksikan menurunkan suplai energi dan menghambat kemampuan terbang dan migrasi dari belalang kembara tersebut. Gambaran mekanisme inhibisi FABP belalang kembara bisa didapatkan dari informasi penghambatan pada FABP manusia yang merupakan protein homolog dan memiliki kekerabatan secara evolusi. Secara evolusi, protein homolog adalah protein dari organisme lain yang mempunyai kemiripan sekuen asam amino dengan protein target dan berasal dari leluhur yang sama (common ancestor). Jika struktur protein yang mempunyai kemiripan dengan protein target sudah dielusidasi secara eksperimental maka struktur 3D protein target bisa diprediksi berdasarkan urutan asam aminonya. Hal ini didasarkan atas prinsip bhawa kemiripan sekuen asam amino yang tinggi ini mengimplikasikan kemiripan struktur 3D protein dan juga fungsinya ( $R$ Shenoy dan Jayaram, 2010). Sekuen asam amino FABP belalang kembara menunjukkan kemiripan sebesar $65 \%$ dan 64\% dengan FABP jantung dan adiposa manusia. Identifikasi inhibitor FABP jantung dan adiposa manusia telah banyak dieksplorasi dalam riset pengembangan obat diabetes (Beniyama dkk., 2013, Cai dkk., 2015, Floresta dkk., 2017, Wang dkk., 2016). Hal ini dilakukan dengan memanfaatkan ketersediaan informasi struktur 3D protein FABP baik yang didapatkan melalui eksperimen kristalografi sinar X, NMR maupun pemodelan komputasional (in silico) atau yang dikenal dengan pendekatan structure-based drug design (SBDD) (Kalyaanamoorthy dan Chen, 2011, Lounnas dkk., 2013, T. Wang dkk., 2016). Turunan pirazol, oxazol, imidazol, indol, tiazol, karbamoil dan pirimidin telah dilaporkan menunjukkan aktivitas penghambatan yang tinggi terhadap FABP adiposa manusia (Floresta dkk., 2017, Wang dkk., 2016). Sebagai contoh senyawa asam 2-(\{[(3,5-diklorofenil) karbamoil] metil $\}$ sulfanill) asetat menunjukkan karakteristik inhibisi yang kuat dan spesifik terhadap FABP adiposa manusia (Cai dkk., 2010). Residu Arg 126 dan Tyr128 pada kantong pengikatan FABP adiposa manusia diketahui memainkan peran penting dalam interaksi ikatan hidrogen. Misalnya, Arg126 bertindak sebagai hidrogen donor ikatan untuk berinteraksi dengan gugus karboksil dan sulfon senyawa inhibitor. Asam amino Phe16 dan Ser53 juga memainkan peran penting dalam afinitas dan selektivitas. Asam amino Phe16 membentuk interaksi $\pi-\pi$ dengan cincin aromatik melalui bantuan residu Ser53. Sehingga dengan demikian informasi tentang asam-asam amino penting dikantong pengikatan FABP homolog dari manusia ini yang menunjukkan interaksi dengan kandidat senyawa inihibitor dapat menjadi petunjuk dalam mengidentifikasi senyawa inhibitor baru terhadap FABP dari belalang kembara menggunakan pendekatan SBDD seperti pemodelan komputasional (in silico), penapisan virtual (virtual screening) maupun penambatan molecular (molecular docking) (Firdaus dkk., 2017; Floresta dkk., 2019, Gaspersz dan Sohilait, 2019; Khan dkk., 2016, La Kilo dkk., 2019, Macalino dkk., 2015). Namun demikian walaupun pendekatan SBDD telah diterapkan secara luas dalam riset bidang farmasi, aplikasinya dalam penelitian di bidang agrokimia masih belum banyak ditemui (Lamberth dkk., 2013). Selain itu sampai saat ini belum pernah ada penelitian yang menerapkan prinsip SBDD dalam mengidentifikasi inhibitor potensial terhadap FABP belalang kembara untuk pengembangan insektisida baru yang selektif.

Oleh sebab itu dalam penelitian ini pemodelan homologi komparatif dengan Phyre2 akan digunakan dengan tujuan untuk (i) membangun model protein target FABP belalang kembara in silico menggunakan templat FABP belalang gurun dan mencit yang kemudian akan digunakan dan (ii) untuk mengidentifikasi kandidat-kandidat inhibitor melalui virtual screening serta docking. Penelitian ini merupakan tahap awal (preliminary) yang bertujuan untuk mendapatkan senyawasenyawa kandidat insektisida yang direkomendasikan untuk divalidasi dan diujikan lebih lanjut secara in vitro di laboratorium maupun on field di lapangan. Implikasi keterbaruan dari penelitian ini tertuju pada penerapan pendekatan pemodelan komputasional (in silico) SBDD dalam tahaptahap awal riset desain dan pengembangan insektisida untuk aplikasi di bidang pertanian dan ketahanan pangan terhadap hama penyakit secara khusus belalang kembara. Kelebihan SBDD yang dibantu teknologi komputasional adalah dalam menawarkan pendekatan baru yang lebih rasional, prediktif, iteratif, cepat, ramah lingkungan yang mendukung kampanye green chemistry dengan 
resiko kecil serta biaya murah dalam riset agrokimia (Shanmugam dan Jeon, 2017).

\section{METODOLOGI}

\section{Perangkat keras (Hardware)}

Seperangkat laptop HP Pavilion x360 Convertible Signature Edition sistem operasi 64bit dengan spesifikasi prosesor Interl(R) Core(TM) i5-6200U CPU @2.30GHz 2.40GHz, RAM 8 GB, harddisk 930 GB.

\section{Perangkat lunak (Software)}

PyRx-Python Prescription 0.8 (The Scripps Research Institute), Poseview versi 1.1.2 (BioSolveIT GmBH, Germany) dan PyMOL Molecular Graphics System versi 2.2.3. (The Schrodinger LLC, New York).

\section{Prosedur Kerja}

Mendapatkan Sekuen Protein Target dan Analisis Penjajaran Sekuen Jamak

Sebanyak 134 asam amino protein FABP belalang kembara (Locusta migratoria) didapatkan dari database UniProtKB (https://www.uniprot.org/) dan disimpan dalam format file FASTA (Consortium, 2014). Analisis penjajaran sekuen jamak antara FABP otot terbang belalang kembara (Locusta migratoria, kode UniProtKB: P41509), FABP otot terbang belalang gurun (Schistocerca gregaria, kode UniProtKB: P41496), FABP Jantung Sapi (Bos taurus, kode UniProtKB: P10790), FABP adiposa Mencit (Mus musculus, kode UniProtKB: P04117) dan FABP jantung manusia (Homo sapiens, kode UniProKB: P05413, PDB: 5HZ9) dilakukan menggunakan Clustal Omega (Sievers dan Higgins, 2018).

\section{Pemodelan Homologi Komparatif}

Sekuen asam amino FABP belalang kembara dijadikan sebagai input (query) untuk memulai pemodelan homologi komparatif menggunakan webserver Phyre2 dengan mode default normal di http://www.sbg.bio.ic.ac.uk/phyre2 (Kelley dkk., 2015).

\section{Evaluasi, Validasi dan Penyempurnaan}

Model 3D FABP belalang kembara yang dibangun tidak lepas dari kesalahan (error) secara stereokimia maupun energi. Server ProSA (Wiederstein dan Sippl, 2007), MolProbity (Chen dkk., 2010) dan SAVES (Structure Analysis and Verification Server) v5.0 yang berisi lima program verifikasi struktural yaitu Verify 3D (Eisenberg dkk., 1997), ERRAT (Colovos dan Yeates, 1993), PROVE (Pontius, Richelle, dan Wodak, 1996), PROCHECK (Laskowski, MacArthur, Moss, dan Thornton, 1993) dan WHATCHECK (Hooft, 1996) digunakan untuk mengevaluasi dan memvalidasi model protein. Model protein FABP belalang kembara yang telah dievaluasi dan divalidasi kemudian disempurnakan menggunakan Galaxy REFINE (Heo dkk., 2013).

\section{Skrining virtual dan docking \\ Tahap I (Penapisan fragmen)}

DOCK Blaster yang menerapkan algoritma docking DOCK 3.6 digunakan untuk skrining pendahuluan sebanyak 1.611 .889 senyawa fragmen kimia yang terdapat di dalam kategori subset \#12 clean fragments dari database ZINC terhadap model protein FABP belalang kembara yang telah dibangun menggunakan templat belalang gurun dan mencit.

\section{Tahap II (Validasi)}

Sebanyak 500 senyawa fragmen yang telah didapat dari hasil virtual screening dengan DOCK Blaster selanjutnya diverifikasi dan dikonfirmasi dengan melakukan re-docking menggunakan server MTi Open Screen (Labbé dkk., 2015). Input data menggunakan model protein FABP belalang kembara dalam file PDB dan 500 senyawa fragmen dalam format file SDF (Structure Data File). Situs aktif dan kantong pengikatan FABP ditentukan berdasarkan atas residu-residu asam amino yang terdapat disitus aktif antara lain yaitu Phe17, Tyr20, Met21, Gly34, Ile41, Leu77, Arg108, Ile117, Ile119, Arg128, Tyr130. Sebanyak 10 top senyawa fragmen kemudian dipilih berdasarkan skor redocking dalam bentuk besaran energi afinitas (kkal/mol), kesesuaian konformasi dan orientasi (pose) fragmen di situs aktif dan kantong pengikatan, juga banyaknya interaksi hidrogen dan hidrofobik yang terbentuk.

\section{Tahap III: Farmakofor, penapisan dan docking senyawa kandidat}

Top fragmen yang didapatkan dari hasil virtual screening dengan model protein FABP belalang kembara menggunakan templat belalang gurun dan mencit kemudian dianalisis fitur-fitur farmakofornya menggunakan PharmaGist 
Fredy Z. Saudale dkk. / Indo. J. Chem. Res., 2020, 7(2), 127 - 140

Tabel 1. Karakteristik cetakan (template) protein yang digunakan dalam pemodelan struktur 3D

FABP belalang kembara menggunakan PHYRE2

\begin{tabular}{|c|c|c|c|c|c|c|c|c|c|}
\hline No & Organisme & $\begin{array}{l}\text { Nama } \\
\text { Protein }\end{array}$ & $\begin{array}{l}\text { Kode } \\
\text { PDB }\end{array}$ & $\begin{array}{c}\% \\
\text { Confidence }\end{array}$ & $\begin{array}{c}\% \\
\text { Identity }\end{array}$ & Apo/Holo & Eksperimen & $\begin{array}{l}\text { Jumlah } \\
\text { residu }\end{array}$ & Referensi \\
\hline 1. & $\begin{array}{l}\text { BelalangGurun } \\
\text { (Schistocerca } \\
\text { gregaria) }\end{array}$ & $\begin{array}{l}\text { FABP } \\
\text { otot } \\
\text { terbang }\end{array}$ & $1 \mathrm{ftp}$ & $100 \%$ & $98 \%$ & Apo & X-Ray, 2,2 $\AA$ & 133 & $\begin{array}{l}\text { (Haunerland } \\
\text { dkk., 1994) }\end{array}$ \\
\hline 2. & $\begin{array}{c}\text { Mencit } \\
\text { (Mus musculus) }\end{array}$ & $\begin{array}{l}\text { FABP } \\
\text { jaringan } \\
\text { lemak }\end{array}$ & $1 \mathrm{~g} 7 \mathrm{n}$ & $100 \%$ & $40 \%$ & Apo & X-Ray, $1,5 \AA$ & 131 & $\begin{array}{c}\text { (Reese dan } \\
\text { Banaszak, } \\
\text { 2004) }\end{array}$ \\
\hline
\end{tabular}

(Schneidman-Duhovny dkk., 2008). Model farmakofor yang telah dibangun kemudian digunakan untuk melakukan virtual screening senyawa-senyawa kandidat (Berat Molekul 300500 gram/mol) menggunakan Pharmit (Sunseri dan Koes, 2016) dengan database dari ZINC Purchasable. Maksimun 10 senyawa top kandidat yang didapatkan kemudian di docking menggunakan PyRx (Dallakyan dan Olson, 2015) untuk mengetahui besarnya energi afinitas (kkal/mol) dan interaksi hidrogen juga hidrofobik yang terbentuk secara 2D menggunakan
Poseview (Stierand dan Rarey, 2010) dan 3D dengan PyMOL (Seeliger dan de Groot, 2010).

\section{HASIL DAN PEMBAHASAN}

Untuk mendapatkan templat protein yang akan digunakan dalam membangun struktur 3D FABP belalang kembara menggunakan pemodelan homologi komparatif Phyre2 berdasarkan tingkat kemiripan susunan asam aminonya maka dilakukan penjajaran sekuen jamak menggunakan Clustal Omega. Didapatkan bahwa residu asam amino FABP otot belalang
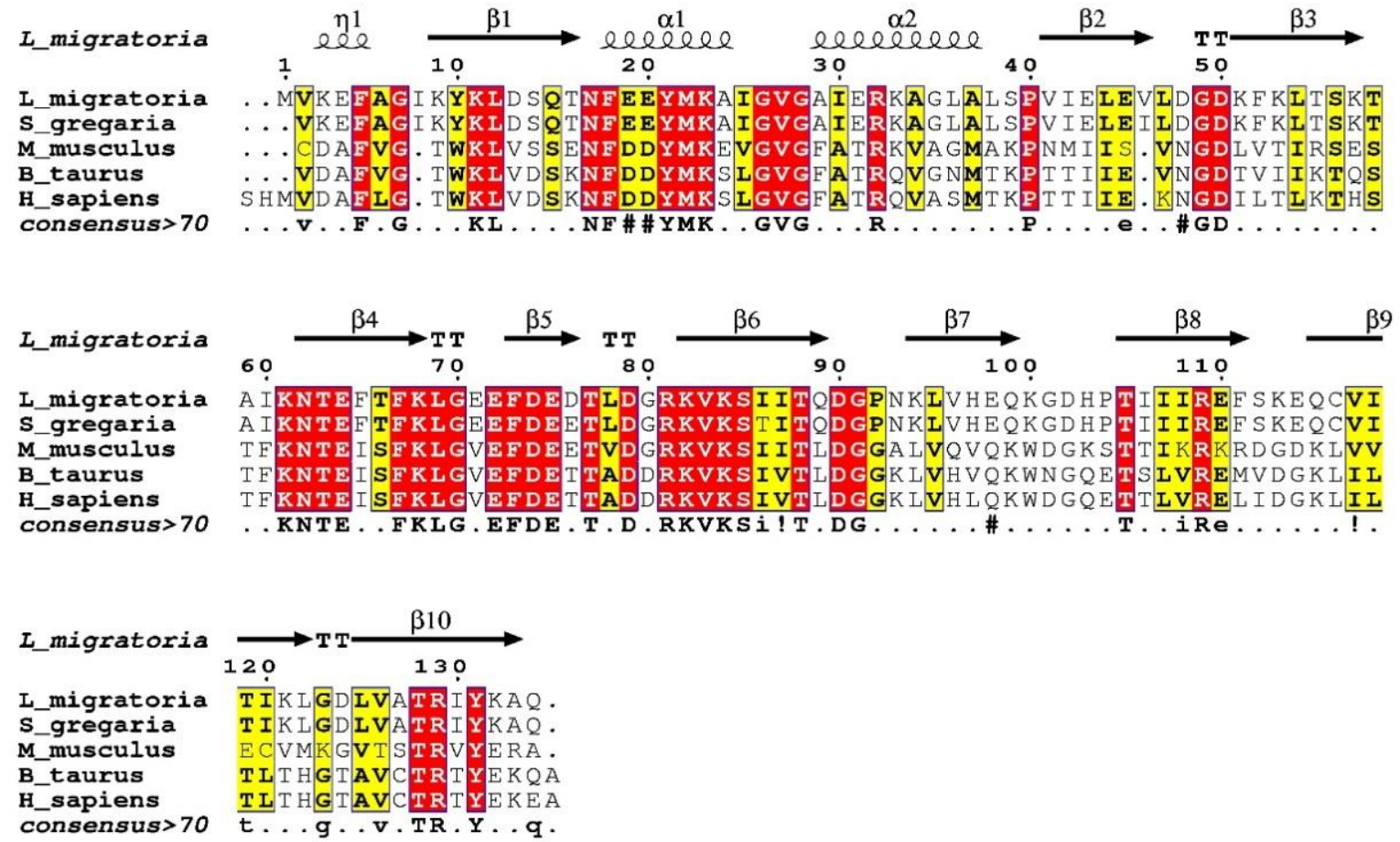

Gambar 1. Analisis penjajaran sekuen jamak antara asam amino FABP otot terbang belalang kembara (Locusta migratoria,), FABP otot terbang belalang gurun (Schistocerca gregaria), FABP Jantung Sapi (Bostaurus), FABP jaringan adiposa Mencit (Mus musculus) dan FABP jantung manusia (Homo sapiens). 


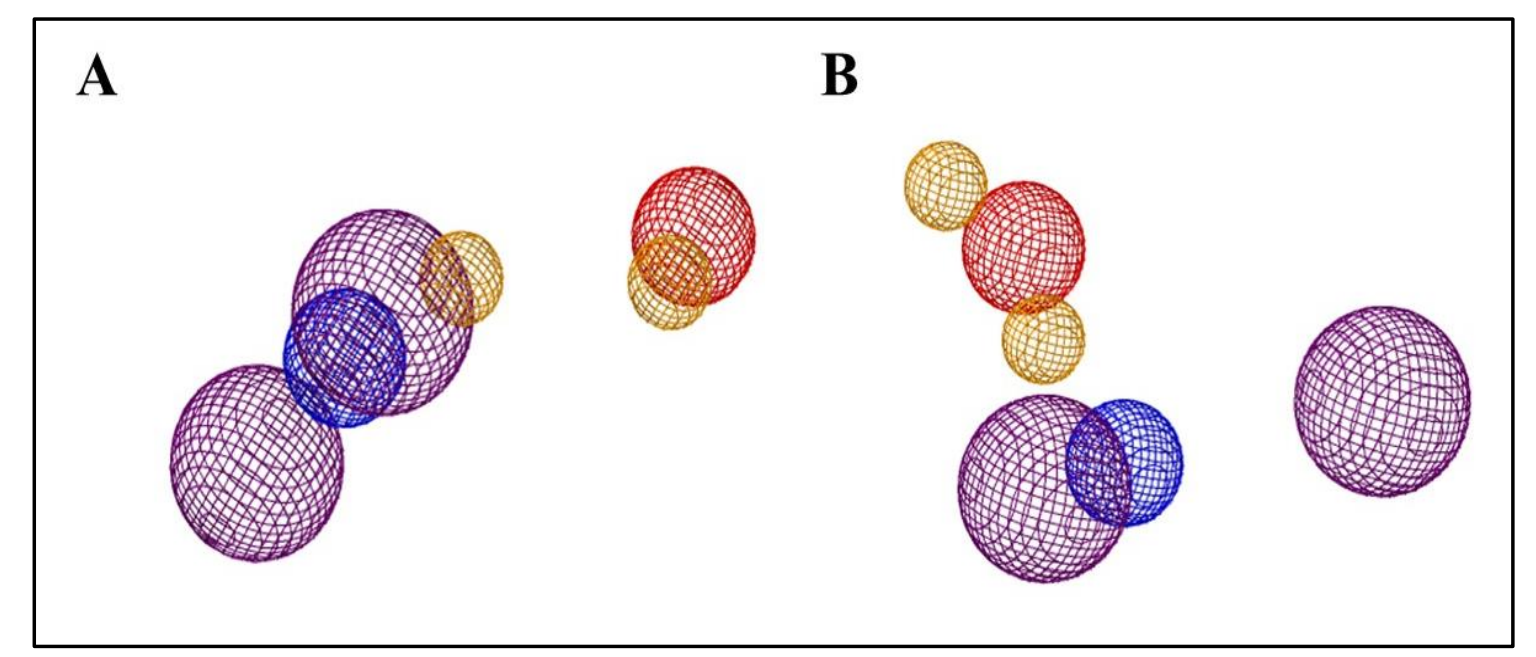

Gambar 2. Fitur farmakofor dari 10 top fragmen yang didapatkan dari skrining virtual model FABP belalang kembara yang dibanun dengan template (A) belalang gurun, $(\mathbf{B})$ mencit. Fitur bulatan yang berwarna merah menunjukkan atom bermuatan negatif, biru menunjukkan atom bermuatan positif, kuning menunjukkan atom penerima ikatan hidrogen.

kembara memiliki persen kesamaan yang tinggi dengan FABP otot belalang gurun yaitu sebesar 97,74\%, dengan FABP jantung sapi 39,69\%, dengan FABP jaringan lemak mencit 38,93\% dan dengan FABP jantung manusia 39,39\% (Gambar 1).

Terlihat asam-asam amino yang berperanan penting dalam berinteraksi dengan substrat asam lemak seperti Thr63, Arg 109, Arg129, Tyr130 yang membentuk ikatan hidrogen tampak lestari (conserved) pada FABP dari semua organisme (Lücke dkk., 2006). Sementara itu Ser56 yang juga berperan dalam membentuk ikatan hidrogen tampak lestari pada FABP belalang kembara, belalang gurun dan mencit, namun bermutasi secara sinonim menjadi Thr56 pada FABP sapi dan manusia. Asam-asam amino non polar yang menstabilkan rantai alifatik dari asam lemak seperti Phe18, Met22, Pro40, Ile106 melalui interaksi hidrofobik juga terlihat lestari pada FABP dari semua organisme. Informasi ini tidak hanya menunjukkan bagaimana asam-asam amino tersebut berperanan sangat esensial dalam menstabilkan interaksi dengan substrat asam lemak, tapi juga menjadi petunjuk dalam mengidentifikasi senyawa-senyawa kimia baru yang dapat menunjukkan interaksi yang sama dengan residu asam amino tersebut. Senyawasenyawa kimia yang dapat menunjukkan interaksi yang sama dengan residu asam amino yang berinteraksi dengan substrat asam lemak berpotensi menjadi kompetitor bagi substrat asam lemak tersebut dengan demikian dapat dikembangkan menjadi inhibitor FABP belalang kembara. Ini yang nanti menjadi dasar dalam pemilihan senyawa kandidat inhibitor melalui virtual screening dan docking.

Berdasarkan analisis penjajaran sekuen jamak maka dipilih FABP belalang gurun dan mencit sebagai templat atau cetakan yang akan digunakan untuk membangun model FABP belalang kembara (Tabel 1). FABP otot belalang gurun dengan persentase asam amino yang identik sebesar $97,74 \%$ diperoleh dari hasil eksperimen kristalografi sinar X dengan resolusi 2,2 A tanpa adanya ligan (Apo) pada struktur kristalnya (Haunerland dkk., 1994). Sementara itu FABP adiposa mencit sebesar 38,93\% didapatkan hasil eksperimen kristalografi sinar $\mathrm{X}$ dengan resolusi 1,5 ̊̊ juga dengan tanpa adanya ligan (Aolo) pada struktur kristalnya (Reese dan Banaszak, 2004).

Kedua tempat ini dipilih untuk mempelajari pengaruh (i) persentase kesamaan asam amino dan (ii) kualitas resolusi kristal yang didapatkan melalui eksperimen kristalografi sinar X terhadap kualitas model FABP belalang kembara yang Model 3D FABP belalang kembara yang didapatkan menggunakan dua templat tersebut diatas dievaluasi dan divalidasi kualitas strukturnya yang kemudian disempurnakan. Tabel 2 menunjukkan bahwa sebelum dilakukan penyempurnaan dengan Galaxy REFINE, model FABP belalang kembara yang dibangun menggunakan templat mencit menunjukkan nilai 
Fredy Z. Saudale dkk. / Indo. J. Chem. Res., 2020, 7(2), 127 - 140

Tabel 1. Karakteristik cetakan (template) protein yang digunakan dalam pemodelan struktur 3D FABP belalang kembara menggunakan PHYRE2

\begin{tabular}{|c|c|c|c|c|c|c|c|c|c|}
\hline No & Organisme & $\begin{array}{l}\text { Nama } \\
\text { Protein }\end{array}$ & $\begin{array}{l}\text { Kode } \\
\text { PDB }\end{array}$ & $\begin{array}{c}\% \\
\text { Confidence }\end{array}$ & $\%$ Identity & Apo/Holo & Eksperimen & $\begin{array}{c}\text { Jumlah } \\
\text { residu }\end{array}$ & Referensi \\
\hline 1. & $\begin{array}{c}\text { BelalangGurun } \\
\text { (Schistocerca } \\
\text { gregaria) }\end{array}$ & $\begin{array}{l}\text { FABP } \\
\text { otot } \\
\text { terbang }\end{array}$ & $1 \mathrm{ftp}$ & $100 \%$ & $98 \%$ & Apo & X-Ray, 2,2 A & 133 & $\begin{array}{l}\text { (Haunerland } \\
\text { et al., 1994) }\end{array}$ \\
\hline 2. & $\begin{array}{l}\text { Mencit } \\
\text { (Mus } \\
\text { musculus) }\end{array}$ & $\begin{array}{l}\text { FABP } \\
\text { jaringan } \\
\text { lemak }\end{array}$ & $1 \mathrm{~g} 7 \mathrm{n}$ & $100 \%$ & $40 \%$ & Apo & X-Ray, $1,5 \AA$ & 131 & $\begin{array}{c}\text { (Reese \& } \\
\text { Banaszak, } \\
\text { 2004) }\end{array}$ \\
\hline
\end{tabular}

Tabel 2. Evaluasi danValidasi 3 model FABP belalang kembara menggunakan template FABP belalang gurun, sapi dan mencit sebelum dan sesudah penyempurnaan dengan GALAXY Refine

\begin{tabular}{|c|c|c|c|c|c|c|c|c|c|}
\hline Template & $\begin{array}{l}\text { GALAXY } \\
\text { Refine }\end{array}$ & $\begin{array}{c}\text { Verify } \\
\text { 3D }\end{array}$ & ERRAT & PROVE & ProSA & MolProbity & $\begin{array}{l}\text { Clash } \\
\text { score }\end{array}$ & $\begin{array}{c}\text { Poor } \\
\text { rotamer }\end{array}$ & $\begin{array}{c}\text { Rama } \\
\text { favored }\end{array}$ \\
\hline \multirow{2}{*}{$\begin{array}{c}\text { Belalang } \\
\text { gurun }\end{array}$} & Sebelum & $100 \%$ & $98,4 \%$ & $3,3 \%$ & $-5,35$ & 2,55 & 13,55 & 13,04 & $90,7 \%$ \\
\hline & Sesudah & $81,95 \%$ & $98,2 \%$ & $4,5 \%$ & $-5,79$ & 1,12 & 3,27 & 0,87 & $95,8 \%$ \\
\hline $\begin{array}{l}\text { Adiposa } \\
\text { mencit }\end{array}$ & Sesudah & $100 \%$ & 100 & $3,6 \%$ & $-8,33$ & 1,18 & 3,89 & 0,00 & $96,6 \%$ \\
\hline
\end{tabular}

Tabel 3. Top hit senyawa kandidat inhibitor hasil virtual screening ZINC Pharmer dengan fitur farmakofor fragmen kimia yang berinteraksi dengan model FABP belalang kembara menggunakan template belalang gurun.

\begin{tabular}{|c|c|c|c|c|c|c|}
\hline No & $\begin{array}{l}\text { ZINC ID } \\
\& \text { Nama }\end{array}$ & Struktur & $\begin{array}{c}\text { Energi } \\
\text { afinitas } \\
\text { (kkal/mol) }\end{array}$ & $\begin{array}{c}\text { Atom } \\
\text { Non } \\
\text { Hidrogen }\end{array}$ & $\begin{array}{l}\text { Efisiensi } \\
\text { ligan }\end{array}$ & $\begin{array}{c}\text { Residu FABP } \\
\text { yang } \\
\text { berinteraksi }\end{array}$ \\
\hline 1. & $\begin{array}{c}\text { C73698912 } \\
2-\{[2- \\
\text { (diphenylamino)- } \\
6-(4- \\
\text { methoxyphenyl) } \\
\text { pyrimidin-4-yl }] \\
\text { oxy }\} \text { acetic acid }\end{array}$ & & $-8,1$ & 32 & 0,26 & $\begin{array}{l}\text { Thr57, Thr62, } \\
\text { Ser55, Met21, } \\
\text { Pro39, Gly34, } \\
\text { Leu77 }\end{array}$ \\
\hline
\end{tabular}

MolProbity yang lebih rendah yakni 1,38 , clash score 6,82, poor rotamers (konformasi rantai samping yang tidak disenangi secara energi struktural) 0,00, serta Rama favoured (jumlah asam amino yang menempati wilayah yang disenangi pada diagram Ramachandran) sebesar 91,4\% dibandingkan yang dengan templat belalang gurun. Hal ini kemungkinan menunjukkan bagaimana kualitas resolusi kristal protein menentukan kualitas model yang didapatkan. Templat mencit mempunyai resolusi kristal yang lebih baik yakni $1,5 \AA$ A dibandingkan templat belalang gurun sebesar 2,2 A. Akurasi dan ketepatan analisis struktur kristal bergantung pada limit resolusi dari kristal dalam rentang 1,53,0 A (Shi, 2014). Struktur kristal yang teratur dan baik mempunyai limit resolusi yang kecil, dan sebaliknya untuk yang tidak teratur dan kurang baik mempunyai limit resolusi yang besar. Semakin bagus resolusi tidak hanya atom-atom rantai utama $(\mathrm{C}, \mathrm{N}, \mathrm{O})$ saja yang bisa terlihat secara detail tapi juga atom $\mathrm{H}$ dari rantai samping, 
bahkan molekul air. Semakin buruk resolusi maka sangat sulit untuk mendapatkan gambaran yang benar dari struktur kristal protein yang akan menjadi masalah besar jika digunakan sebagai templat dalam pemodelan homologi komparatif. Namun demikian, setelah penyempurnaan dengan Galaxy REFINE model menambat di kantong pengikatan sehingga bisa mempengaruhi interpretasi hasil virtual screening dan docking.

Hasil skrining virtual dengan DOCK Blaster, dan validasi menggunakan MTI Open Screen didapatkan 10 top fragmen yang berinteraksi dengan model FABP belalang kembara distus

Tabel 4. Interaksi 2D dan 3D antara senyawa kandidat terbaik dengan model FABP belalang kembara yang dibangun menggunakan template belalang gurun

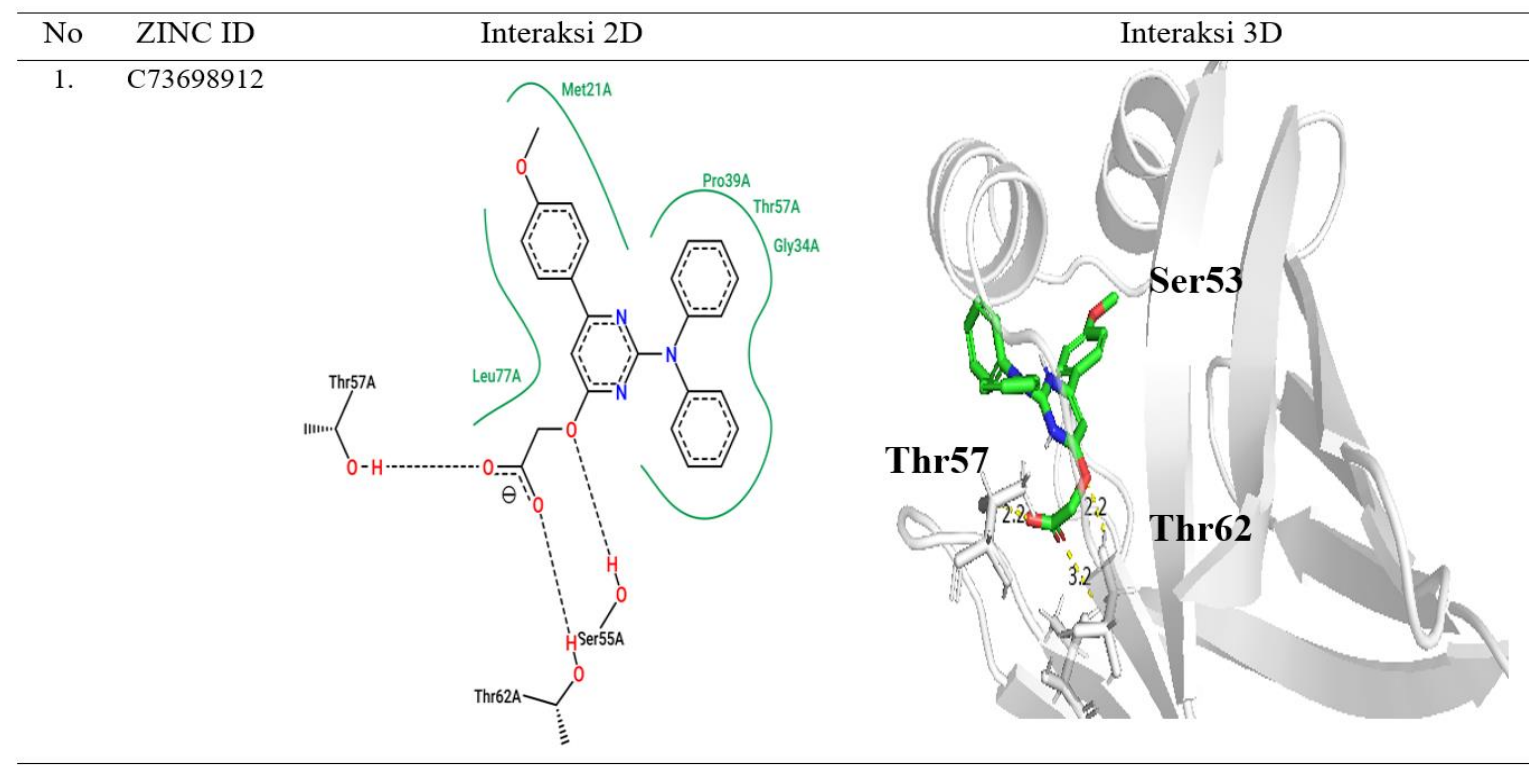

FABP belalang kembara yang dibangun dari templat belalang gurun mengalami perbaikan nilai PROVE menjadi $4,5 \%$, ProSA $-5,79$, MolProbity 1,12, clash score 3,27, poor rotamers 0,87, dan Rama favoured sebesar 95,8\%. Demikian juga model FABP belalang kembara yang dibangun dengan templat mencit juga mengalami perbaikan pada nilai ERRAT menjadi $100 \%$, PROVE 3,6\%, MolProbity 1,18, clash score 3,89, dan asam amino yang menempat wilayah yang disukai pada plot Ramachandran sebesar 96,6\%. Dari data ini dapat dikatakan bahwa penyempurnaan dapat memperbaiki error stereokimia maupun energi struktural dari model yang dibangun dari kualitas templat yang berbeda. Galaxy REFINE menyempurnakan model dengan melakukan pengepak ulang rantai samping dengan melakukan minimisasi struktur melalui simulasi dinamika molekuler singkat selama 0,2 ps secara berulang (iteratif yang mampu merelaksasi, mengurangi ketegangan struktur dan meminimalkan energinya (Heo et al., 2013). Ketegangan struktur dapat meningkatkan benturan atom yang akan mempengaruhi kemampuan senyawa kandidat inhibitor untuk aktif pengikatan. Untuk model FABP yang dibangun dengan templat belalang gurun diperoleh 10 fragmen kimia terbaik berdasarkan rentang energi afinitas dari $-7,8$ hingga -8.0 $\mathrm{kkal} / \mathrm{mol}$ serta ketepatan pose atau konformasi pengikatan dengan protein.

Dari ke 10 top fragmen ini kemudian dilakukan analisis farmakofor yang merupakan sekumpulan fitur sterik dan elektronik yang diperlukan untuk memastikan interaksi yang optimal antara ligan dengan protein target yang bertujuan untuk menginduksi atau menginhibisi respons biologisnya (Koes, 2016). Analisis farmakofor dari ke-10 top fragmen tersebut menunjukkan kesamaan fitur farmakofor yang dimiliki yaitu 2 cincin aromatik, 1 atom bermuatan positif, 1 atom bermuatan negatif, dan 2 akseptor hidrogen. (Gambar 2A). Fitur-fitur farmakofor yang dihasilkan ini kemudian digunakan sebagai input untuk melakukan skrining virtual dengan Pharmit terhadap senyawa-senyawa kandidat (300-500 Dalton) yang ada di dalam database ZINC Purchasable 
Fredy Z. Saudale dkk. / Indo. J. Chem. Res., 2020, 7(2), 127 - 140

(Sunseri dan Koes, 2016). Skrining virtual farmakofor ini dengan database ZINC Purchasable mendapatkan satu senyawa kandidat baru C73698912 dengan berat molekul 427,48 gram/mol yang merupakan turunan dari pirimidin (Tabel 3).
Docking C73698912 dengan model FABP belalang kembara yang dibangun dengan templat belalang gurun memberikan energi afinitas sebesar $-8,1 \mathrm{kkal} / \mathrm{mol}$.

Tabel 5. Top hit senyawa kandidat inhibitor hasil virtual screening ZINC Pharmer dengan fitur farmakofor fragmen yang berinteraksi dengan model FABP belalang kembara menggunakan template mencit

\begin{tabular}{|c|c|c|c|c|c|c|}
\hline No & $\begin{array}{l}\text { ZINC ID } \\
\& \text { Nama }\end{array}$ & Struktur & $\begin{array}{c}\text { Energi } \\
\text { afinitas } \\
\text { (kkal/mol) }\end{array}$ & $\begin{array}{c}\text { Atom Non } \\
\text { Hidrogen }\end{array}$ & $\begin{array}{l}\text { Efisieni } \\
\text { ligan }\end{array}$ & $\begin{array}{c}\text { Residu FABP } \\
\text { yang } \\
\text { berinteraksi }\end{array}$ \\
\hline 1. & $\begin{array}{c}\text { C00628966 } \\
\text { (2-carboxyethyl)- } \\
\text { triazahexacyclo, } \\
\text { tricosa-undecaen-4- } \\
\text { ylium }\end{array}$ & & $-10,2$ & 28 & 0,36 & $\begin{array}{c}\text { Ser53, Phe16, } \\
\text { Val75, } \\
\text { Val115, } \\
\text { Gln93 }\end{array}$ \\
\hline 2. & $\begin{array}{c}\text { C15721579 } \\
\text { (2S)-2-acetamido-3- } \\
{[1-} \\
\text { (triphenylmethyl)- } \\
\text { 1H-imidazol-4-yl] } \\
\text { propanoic acid }\end{array}$ & & $-8,5$ & 33 & 0,26 & $\begin{array}{c}\text { Ser53, Tyr19, } \\
\text { Arg126, } \\
\text { Cys117, } \\
\text { Ile104, Met20 }\end{array}$ \\
\hline 3. & $\begin{array}{c}\text { C13640660 } \\
\text { (3Z)-3-(1H-1,3- } \\
\text { benzodiazol-2-yl)-4- } \\
\text { (4-bromophenyl) } \\
\text { but-3-enoic acid }\end{array}$ & & $-8,3$ & 27 & 0,31 & $\begin{array}{l}\text { Ser53, Phe16, } \\
\text { Ile104, Val75 }\end{array}$ \\
\hline 4. & $\begin{array}{c}\text { C36208749 } \\
\text { 3-[1- } \\
\text { (triphenylmethyl)- } \\
\text { 1H-imidazol-4- } \\
\text { yl]propanoic acid }\end{array}$ & & $-8,3$ & 29 & 0,29 & $\begin{array}{c}\text { Ser53, } \\
\text { Met20, } \\
\text { Gln95, } \\
\text { Val75, Val23, } \\
\text { Phe16 }\end{array}$ \\
\hline 5. & $\begin{array}{c}\text { C77291184 } \\
\text { 4-[[2-Butyl-5-(2,2- } \\
\text { dicarboxyvinyl)-1H- } \\
\text { imidazol- } \\
\text { 1yl)methylbenzoic } \\
\text { Acid }\end{array}$ & & $-8,2$ & 27 & 0,30 & $\begin{array}{l}\text { Thr60, Ser53, } \\
\text { Phe16, } \\
\text { Val15, Ile104 }\end{array}$ \\
\hline 6. & $\begin{array}{c}\text { C72127248 } \\
\text { 2-[2-(1-methyl-1H- } \\
\text { imidazol-2-yl) } \\
\text { benzoyl]-2,8- } \\
\text { diazaspiro [4.5] } \\
\text { decane-3- }\end{array}$ & & $-7,0$ & 27 & 0,26 & $\begin{array}{l}\text { Ser53, Phe16, } \\
\text { Val75, } \\
\text { Phe16, } \\
\text { Met20, Ile26, } \\
\text { Thr60 }\end{array}$ \\
\hline
\end{tabular}


Fredy Z. Saudale dkk. / Indo. J. Chem. Res., 2020, 7(2), 127 - 140

Tabel 6. Interaksi 2D dan 3D antara senyawa kandidat terbaik dengan model FABP belalang kembara yang dibangun menggunakan template mencit

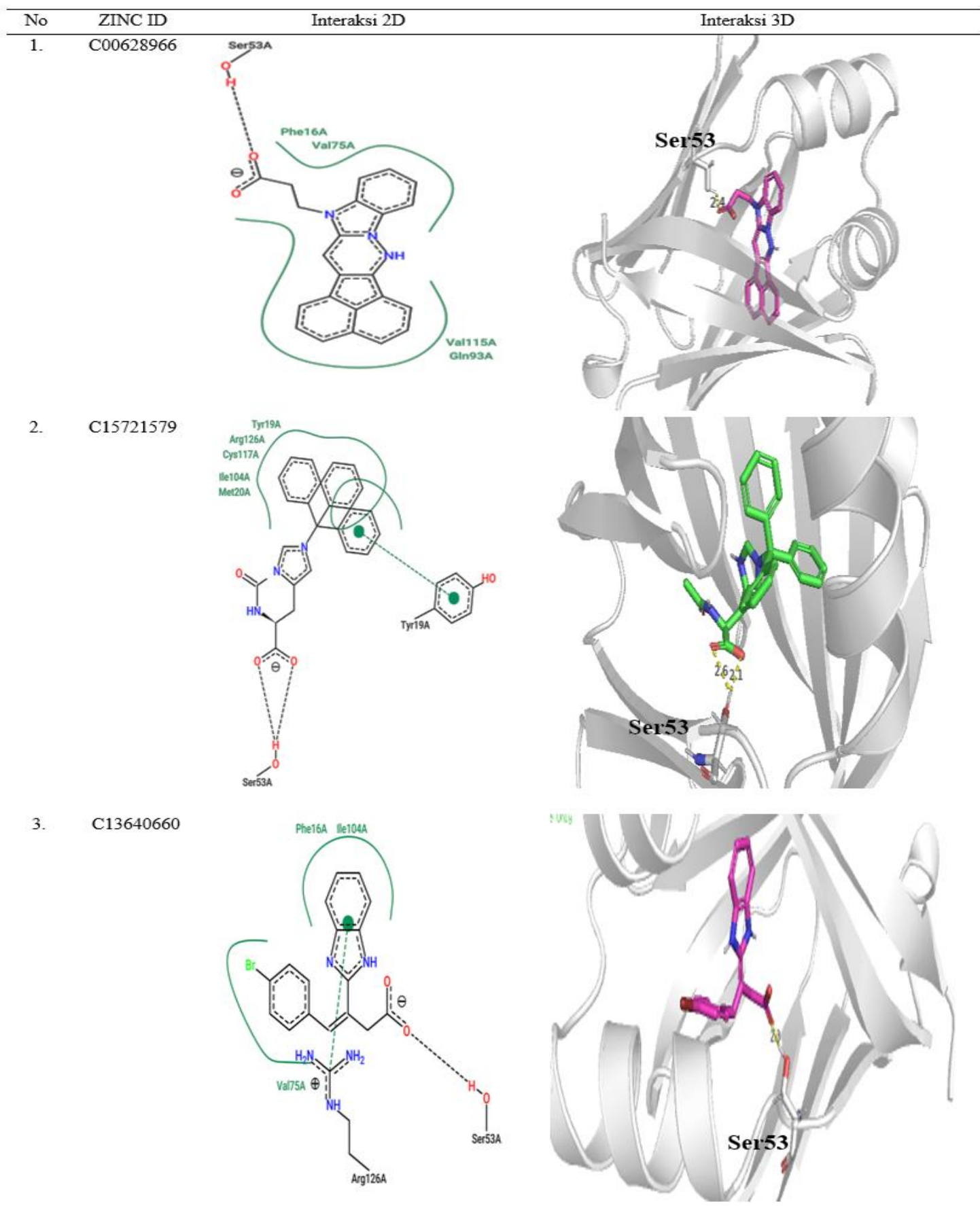


Fredy Z. Saudale dkk. / Indo. J. Chem. Res., 2020, 7(2), 127 - 140

4. $\mathrm{C} 36208749$
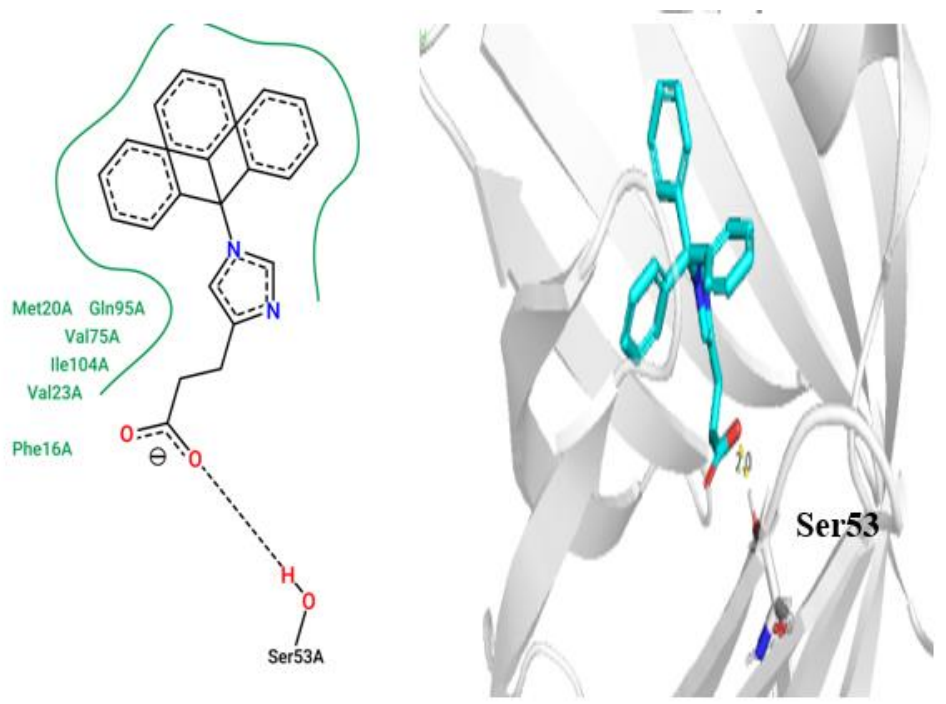

5. $\mathrm{C} 77291184$
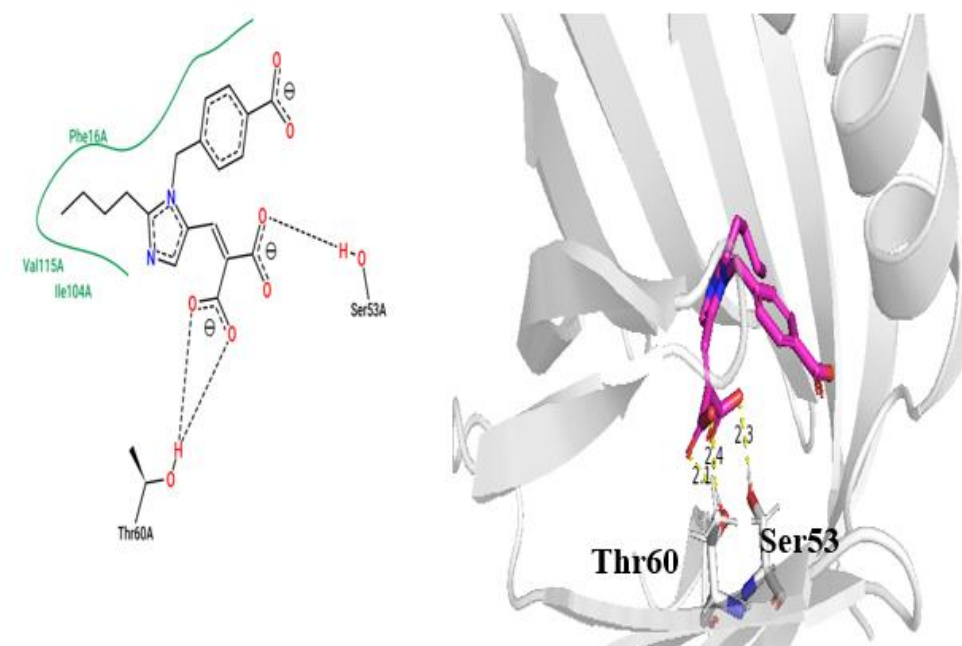

6. $\mathrm{C} 72127248$
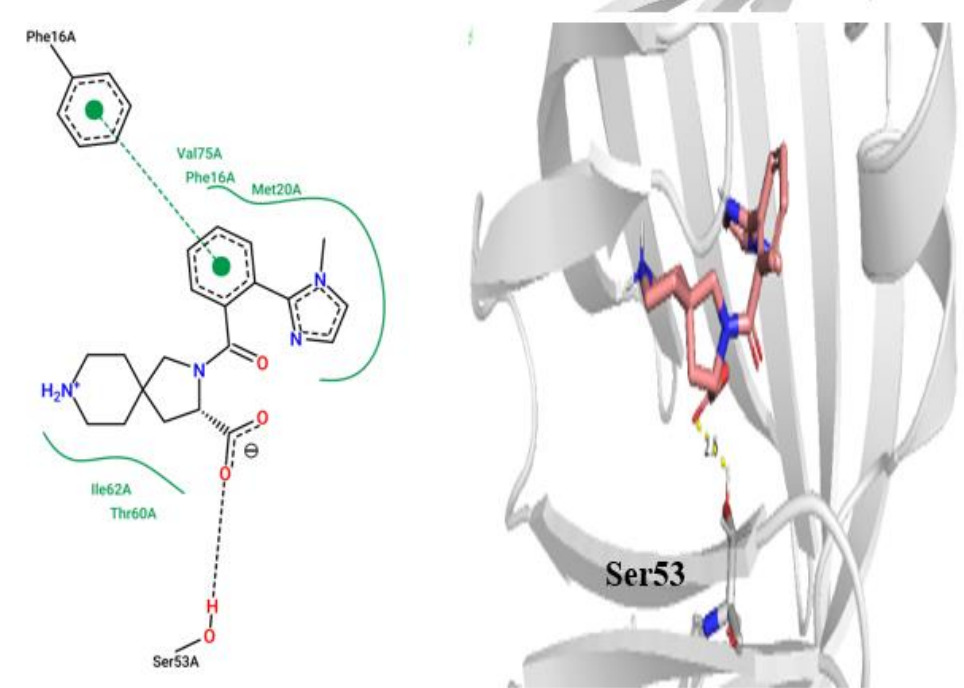

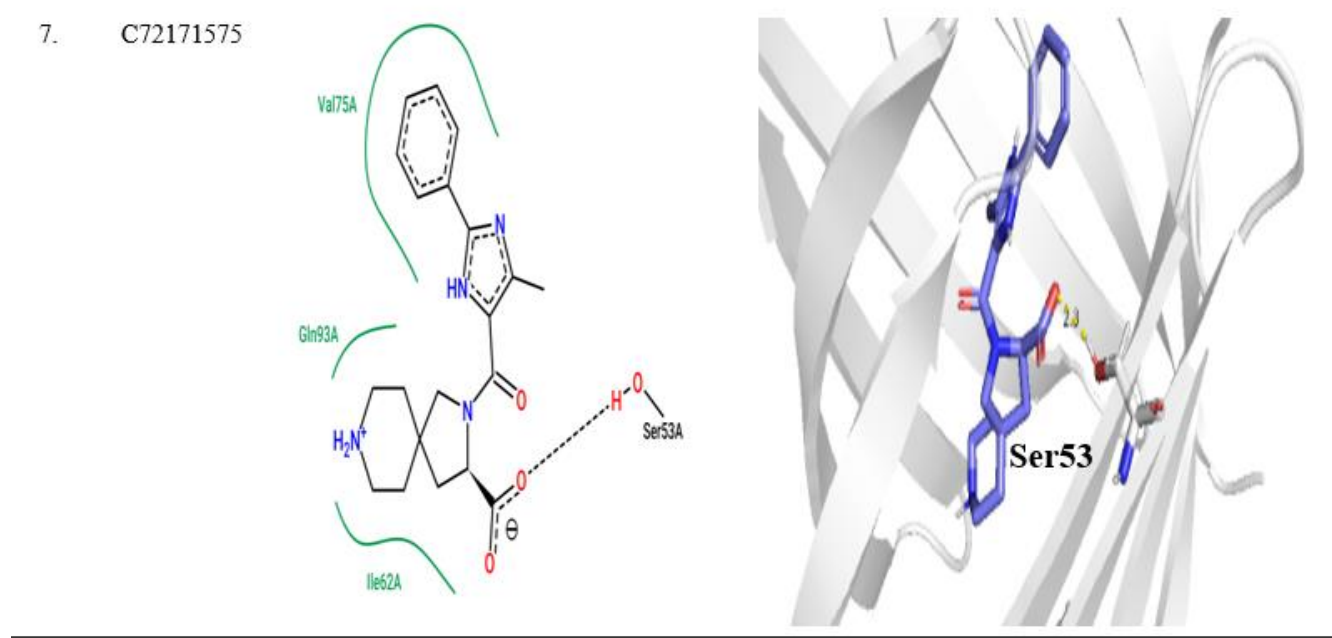

Ikatan ini distabilkan melalui ikatan hidrogen antara gugus karboksiltat dengan Thr57, Thr62, Ser55 dengan jarak masing-masing $3,2 \AA$, $3,2 \AA ̊$ dan $2,2 \AA$ serta melalui interaksi hidrofobik Met21, Pro39, Gly34 dan Leu77 (Tabel 4). Interaksi senyawa C73698912 dengan FABP belalang kembara menyerupai perilaku interaksi antara inhibitor turunan karbamoil dengan FABP adiposa manusia dimana ikatan hidrogen yang terbentuk oleh Ser55 berperanan penting dalam afinitas dan selektifitas (Cai et al., 2010). Namun berbeda dengan senyawa turunan pirimidin yakni 4-hidroksipirimidin yang telah didapati sebgai inhibitor FABP4 yang cukup kuat dan selektif oleh (Ringom et al., 2004), analisis struktur kristal menunjukkan bahwa gugus hidroksil pada pirimidin membentuk interaksi hidrogen dengan Tyr128 dan Arg126 dengan cara yang mirip dengan gugus karboksilat dari substrat asam lemak rantai panjang. Sementara itu cincin aromatik terletak pada kanting lipofilik yang diisi oleh residu Phe16, Met20, Val23, Ala33, Phe57, dan Ala75.

Sementara itu untuk model FABP belalang kembara yang dibangun dengan templat dari mencit didapatkan 10 top fragmen terbaik berdasarkan rentang energi afinitas dari $-8,2$ hingga $-9.0 \mathrm{kkal} / \mathrm{mol}$ serta ketepatan pose atau konformasi pengikatan dengan protein. Kesepuluh top fragmen memiliki fitur farmakofor sebanyak 2 cincin aromatik, 2 hidrogen askeptor, 1 atom bermuatan positif dan 1 atom bermuatan negatif (Gambar 2B). Skrining virtual farmakofor 10 top fragmen yang berinteraksi dengan FABP belalang kembara yang dibangun dengan template mencit diperoleh tujuh (7) senyawa kandidat inhibitor yaitu C00628966, C15721579, C13640660, C36208749, C77291184, C72127248 dan C72171575 dengan energi afinitas secara berturut-turut ialah $-10,2 \mathrm{kkal} / \mathrm{mol}$, $-8,5 \mathrm{kkl} / \mathrm{mol},-8,3 \mathrm{kkal} / \mathrm{mol},-8,3 \mathrm{kkal} / \mathrm{mol},-8,2$ $\mathrm{kkal} / \mathrm{mol},-7,0 \mathrm{kkal} / \mathrm{mol}$ dan $-6,7 \mathrm{kkal} / \mathrm{mol}$ (Tabel 5). Beberapa senyawa kandidat ini merupakan turunan imidazol (C15721579, C36208749, C77291184, C72127248, C72171575) dan benzodiazol (C13640660). Senyawa-senyawa kandidat tersebut distabilkan oleh Ser53 dan Thr60, melalui interaksi hidrogen dan Phe16, Val75, Val23, Val115, Ile26, Ile62, Gln95, Gln93, Tyr19, Arg126, Cys117, Ile104, Met20 melalui interaksi hidorofobik (Tabel 6). Sejalan dengan hasil yang didapatkan, inhibitor turunan imidazol terhadap protein FABP yang pernah didapatkan adalah BMS309403 yang juga menunjukkan bagaimana residu asam amino Ser53 berperanan penting dalam menstabilkan afinitas ikatan intrinsik dengan cincin azol (Sulsky et al., 2007).

Semua kandidat inhibitor yang telah didapatkan menunjukkan afinitas yang tinggi dengan model FABP belalang kembara dibandingkan dengan afinitas FABP dengan substrat asli asam oleat $(-5,5 \mathrm{kkal} / \mathrm{mol})$. Hal ini menunjukkan bahwa semua kandidat inhibitor dapat menjadi kompetitor bagi substrat asam oleat. Ini dapat dihipotesiskan dengan masuknya senyawa kandidat inhibitor maka akan menghalangi transport asam lemak oleh FABP ke mitokondria menghasilkan energi. Sehingga diprediksi inhibisi tersebut dapat mempengaruhi kemampuan terbang dan bermigrasi dari belalang kembara. Namun demikian hipotesis ini serta 
prediksi in silico interaksi senyawa inhibitor disitus aktif FABP belalang kembara masih perlu ditindaklanjuti melalui validasi dan pengujian in vitro di laboratorium.

\section{KESIMPULAN}

Pemodelan homologi komparatif menggunakan Phyre2 menghasilkan dua model FABP belalang kembara yang dibangun menggunakan templat belalang gurun dan mencit. Model FABP yang dibangun menunjukkan kualitas stereokimia dan energi struktural dengan batasan nilai yang bisa diterima setelah dilakukan penyempurnaan. Virtual screening dan docking model FABP belalang kembara mendapatkan senyawa turunan pirimidin, imidazol dan benzodiazol sebagai kandidat senyawa inhibitor yang menunjukkan afinitas yang tinggi serta konformasi yang menyerupai inhibitor yang serupa yang telah diketahui aktivitasnya terhadap protein FABP homolog pada manusia.

Hasil ini menunjukkan bahwa pendekatan SBDD melalui pemodelan komputasional, virtual screening dan docking dapat diterapkan pada tahap awal riset desain dan pengembangan insektisida yang selektif untuk mendapatkan senyawa-senyawa kandidat yang menunjukkan interaksi yang mirip dengan inhibitor komersial untuk dapat direkomendasikan menuju tahap pengujian dan validas lebih lanjut secara in vitro maupun in vivo.

\section{DAFTAR PUSTAKA}

Beniyama, Y., Matsuno, K., Miyachi, H., 2013, Structure-guided design, synthesis and in vitro evaluation of a series of pyrazole-based fatty acid binding protein (FABP) 3 ligands, Bioorg.Med. Chem. Lett., 23(6), 1662-1666.

Cai, H., Liu, Q., Gao, D., Wang, T., Chen, T., Yan, G., Chen, K., Xu, Y., Wang, H., Li, Y., 2015, Novel fatty acid binding protein 4 (FABP4) inhibitors: Virtual screening, synthesis and crystal structure determination, Eur. J. Med. Chem., 90, 241-250.

Cai, H., Yan, G., Zhang, X., Gorbenko, O., Wang, H., Zhu, W., 2010, Discovery of highly selective inhibitors of human fatty acid binding protein 4 (FABP4) by virtual screening, Bioorg.Med. Chem. Lett, 20(12), 3675-3679.

Chen, V. B., Arendall, W. B., Headd, J. J., Keedy, D. A., Immormino, R. M., Kapral, G. J., Murray, L. W., Richardson, J. S.,
Richardson, D. C., 2010, MolProbity: Allatom structure validation for macromolecular crystallography, Acta. Crystallogr. D. Biol. Crystallogr., 66(1), 1221.

Consortium, U., 2014, UniProt: A hub for protein information, Nucleic. Acids. Res., 43(D1), D204-D212.

Cortés-Eslava, J., Gómez-Arroyo, S., Risueño, M. C., Testillano, P. S., 2018, The effects of organophosphorus insecticides and heavy metals on DNA damage and programmed cell death in two plant models. Environmental Pollution, 240, 77-86.

Dallakyan, S., Olson, A. J., 2015, Small-molecule library screening by docking with PyRx. In Chemical biology (pp. 243-250). Springer.

Firdaus, F., Dali, S., Rusman, H. J., 2017, Imobilisasi Enzim Lipase Dedak Padi (Oryza Sativa L.) Pada Karbon Aktif: Karakterisasi, dan Uji Stabilitas Kerja Enzim Imobil, Indo. J. Chem. Res., 5(1), 32-36.

Floresta, G., Gentile, D., Perrini, G., Patamia, V., Rescifina, A., 2019, Computational Tools in the Discovery of FABP4 Ligands: A Statistical and Molecular Modeling Approach, Mar. Drugs., 17(11), 624.

Floresta, G., Pistara, V., Amata, E., Dichiara, M., Marrazzo, A., Prezzavento, O., Rescifina, A., 2017, Adipocyte fatty acid binding protein 4 (FABP4) inhibitors. A comprehensive systematic review, Eur. J. Med. Chem., 138, 854-873.

Gaspersz, N., Sohilait, M. R., 2019, Penambatan Molekuler $\alpha, \beta$, dan $\gamma$-mangostin Sebagai Inhibitor $\alpha$-amilase Pankreas Manusia. Indo. J. Chem. Res., 6(2), 59-66.

Haunerland, N. H., Jacobson, B. L., Wesenberg, G., Rayment, I., Holden, H. M., 1994, Threedimensional structure of the muscle fattyacid-binding protein isolated from the desert locust Schistocerca gregaria, Biochemistry, 33(41), 12378-12385.

Heo, L., Park, H., Seok, C., 2013, GalaxyRefine: Protein structure refinement driven by sidechain repacking, Nucleic. Acids. Res., 41(W1), W384-W388.

Hotamisligil, G. S., Bernlohr, D. A., 2015, Metabolic functions of FABPsMechanisms and therapeutic implications, Nat. Rev. Endocrinol., 11(10), 592.

Kalyaanamoorthy, S., Chen, Y.-P. P., 2011, Structure-based drug design to augment hit 
discovery, Drug. Discov. Today., 16(17-18), 831-839.

Kelley, L. A., Mezulis, S., Yates, C. M., Wass, M. N., Sternberg, M. J. E., 2015, The Phyre2 web portal for protein modeling, prediction and analysis, Nat. Protoc., 10(6), 845-858.

Khan, F. I., Wei, D.-Q., Gu, K.-R., Hassan, M. I., Tabrez, S., 2016, Current updates on computer aided protein modeling and designing, Int. J. Biol. Macromol., 85, 4862.

Koes, D. R., 2016, Pharmacophore Modeling: Methods and Applications. In W. Zhang (Ed.), Computer-Aided Drug Discovery (pp. 167-188). Springer New York.

La Kilo, A., Sabihi, I., La Kilo, J., 2019, Studi Potensi Pirazolin Tersubstitusi 1-N dari Thiosemicarbazone sebagai Agen Antiamuba melalui Uji In Silico. Indo. J. Chem. Res., 7(1), 9-24.

Labbé, C. M., Rey, J., Lagorce, D., Vavruša, M., Becot, J., Sperandio, O., Miteva, M. A., 2015, MTiOpenScreen: A web server for structure-based virtual screening, Nucleic. Acids. Res., 43(W1), W448-W454.

Lamberth, C., Jeanmart, S., Luksch, T., Plant, A., 2013, Current challenges and trends in the discovery of agrochemicals, Science, 341(6147), 742-746.

Lassa, J. A., 2017, The Return of Locust Outbreak in Sumba, Indonesia: A Rapid Situational Analysis. Working Paper\# 17, Institute of Resource Governance and Social Change (IRGSC).

Lounnas, V., Ritschel, T., Kelder, J., McGuire, R., Bywater, R. P., Foloppe, N., 2013, Current progress in structure-based rational drug design marks a new mindset in drug discovery, Comput. Struc. Biotechnol. J., 5(6), e201302011.

Lücke, C., Qiao, Y., Van Moerkerk, H. T., Veerkamp, J. H., Hamilton, J. A., 2006, Fatty-acid-binding protein from the flight muscle of Locusta migratoria: Evolutionary variations in fatty acid binding, Biochemistry, 45(20), 6296-6305.

Macalino, S. J. Y., Gosu, V., Hong, S., Choi, S., 2015, Role of computer-aided drug design in modern drug discovery, Arch. Pharm. Res., 38(9), 1686-1701.

Nawaz, A., Gogi, M. D., Sufyan, M., 2016, InsectPests in Dryland Agriculture and their Integrated Management, In Innovations in
Dryland Agriculture (pp. 143-186). Springer.

R Shenoy, S., Jayaram, B., 2010, Proteins: Sequence to structure and function-current status, Curr. Protein. Pept. Sci., 11(7), 498514.

Reese, A. J., Banaszak, L. J., 2004, Specificity determinants for lipids bound to $\beta$-barrel proteins, J. Lipid. Res., 45(2), 232-243.

Ringom, R., Axen, E., Uppenberg, J., Lundbäck, T., Rondahl, L., Barf, T., 2004, Substituted benzylamino-6-(trifluoromethyl) pyrimidin4 (1H)-ones: A novel class of selective human A-FABP inhibitors, Bioorg.Med. Chem. Lett., 14(17), 4449-4452.

Seeliger, D., de Groot, B. L., 2010, Ligand docking and binding site analysis with PyMOL and Autodock/Vina, J. Comput. Aided. Mol. Des., 24(5), 417-422.

Shanmugam, G., Jeon, J., 2017, Computer-aided drug discovery in plant pathology, Plant. Pathol. J., 33(6), 529.

Shi, Y., 2014, A glimpse of structural biology through X-ray crystallography, Cell, 159(5), 995-1014.

Sievers, F., Higgins, D. G., 2018, Clustal Omega for making accurate alignments of many protein sequences, Protein. Sci., 27(1), 135145.

Stierand, K., Rarey, M., 2010, PoseViewmolecular interaction patterns at a glance, $J$. Cheminform., 2(S1), P50.

Sulsky, R., Magnin, D. R., Huang, Y., Simpkins, L., Taunk, P., Patel, M., Zhu, Y., Stouch, T. R., Bassolino-Klimas, D., Parker, R., 2007, Potent and selective biphenyl azole inhibitors of adipocyte fatty acid binding protein (aFABP), Bioorg.Med. Chem. Lett., 17(12), 3511-3515.

Sunseri, J., Koes, D. R., 2016, Pharmit: Interactive exploration of chemical space, Nucleic. Acids. Res., 44(W1), W442-W448.

Wang, T., Wu, M.-B., Zhang, R.-H., Chen, Z.-J., Hua, C., Lin, J.-P., Yang, L.-R., 2016, Advances in computational structure-based drug design and application in drug discovery, Curr. Top. Med. Chem., 16(9), 901-916.

Wang, Y.-T., Liu, C.-H., Zhu, H.-L., 2016, Fatty acid binding protein (FABP) inhibitors: A patent review (2012-2015), Expert. Opin. Ther. Pat., 26(7), 767-776.

Wiederstein, M., Sippl, M. J., 2007, ProSA-web: Interactive web service for the recognition of 
Fredy Z. Saudale dkk. / Indo. J. Chem. Res., 2020, 7(2), 127 - 140

errors in three-dimensional structures of proteins, Nucleic. Acids. Res., 35(suppl_2), W407-W410.
Yang, M. L., Zhang, J. Z., Zhu, K. Y., Xuan, T., Liu, X. J., Guo, Y. P., Ma, E. B., 2009, Mechanisms of organophosphate resistance in a field population of oriental migratory locust, Locusta migratoria manilensis (Meyen), Arch. Insect. Biochem. Physiol., 71(1), 3-15. 